\title{
レール波状摩耗の成長機構解析のための弾性支床梁モデルの検証
}

\author{
網干 光雄 ${ }^{* 1}$, 田中 博文 ${ }^{* 1}$
}

\section{Verification of elastically supported beam model for growth mechanism analysis of rail corrugation}

\author{
Mitsuo ABOSHI ${ }^{* 1}$ and Hirofumi TANAKA ${ }^{* 1}$ \\ ${ }^{* 1}$ Railway Technical Research Institute \\ 2-8-38 Hikari-cho, Kokubunji-shi, Tokyo 185-8540, Japan
}

\section{Received: 6 September 2019; Revised: 16 December 2019; Accepted: 4 February 2020}

\begin{abstract}
Rail corrugation that causes the vibration and the noise is a phenomenon in which roughness patterns of approximately regular wavelengths are formed on the rail running surface by trains running. In the previous paper, we have already explained the growth mechanism and the wavelength determination mechanism of the rail corrugation from the dynamic point of view and verified their validity by comparing them with the field data. In this paper, we verify three influence factors of the elastically supported beam model left as subjects in the previous paper. As a result of analyses, it is confirmed that when the track structure is usually used type, the effect of the rail axial force on the growth mechanism of the rail corrugation and the error compared with the analysis results by the model of the moving coordinate system are negligible, and the analysis by the elastically supported beam model is valid including at near the anti-resonance frequency of the elastic support track system.
\end{abstract}

Keywords : Railway, Track, Corrugation, Pattern formation, Wave motion, Vibration of continuous system

\section{1. 緒言}

レール波状摩耗は，鉄道車両の走行に伴って軌道のレール頭頂面に規則的な波長の凹凸パターンが形成される もので，振動や騒音の発生原因となっている（石田，2005）。レール波状摩耗は発生箇所や波長などにさまざまな 形態が見られ，発生メカニズムについても調査や研究が行われているが（例えば，須田他，1988，Grassie and Kalousek, 1993，松本他，1996，Igeland，1996，Manabe，2000，田中他，2009）, の現象の発生機構や波長決定 メカニズムは十分解明されているとは言えない.

そこで著者らは，軌道と車両の相互作用を考慮した解析モデルを用いて，車両走行によるレール凹ウ振幅の成 長機構とその波長決定メカニズムを動力学観点から統一的に説明するとともに，営業線における波状摩耗の発生 状況と比較することでその妥当性を検証してきた（網干，田中，2019a；以降，「前報告」という）。しかし，この 解析で用いた軌道の弾性支床梁モデルでは，レールの軸力を考慮していないこと，車両の走行をレール凹凸の位 相変化で模擬していること，さらに，まくらぎ間隔でレールが離散支持される軌道構造を連続支床としてモデル 化していることから，これらの要因がレール波状摩耗の成長機構に与える影響が明確ではないという課題が残さ れている.

本論文では，軌道を弾性支床梁モデルとして扱うことに関して，前報告で課題として残されていたレールの軸 力による影響や，移動座標系による解析結果との差異，離散支持梁を連続支床梁としてモデル化することの動力 学的な妥当性を検討し，これらの要因が軌道の応答特性ならびにレール波状摩耗の成長機構に与える影響を検証

No.19-00331 [DOI:10.1299/transjsme.19-00331], J-STAGE Advance Publication date : 14 February, 2020

*1 正員，（公財）鉄道総合技術研究所（一185-8540 東京都国分寺市光町 2-8-38）

E-mail of corresponding author: aboshi.mitsuo.08@rtri.or.jp 
する.

\section{2. 軌道の弾性支床梁モデルとレール波状摩耗の成長機構}

本章では, 前報告で示した波状摩耗の成長機構と波長決定メカニズムを要約するとともに，3 章以降での解析 結果と比較するため，標準的なパラメータによる計算例を示す.

\section{$2 \cdot 1$ 解析モデル}

図 1 に，凹凸（振幅 $A_{R}$, 波長 $\lambda_{R}$ ）のある弾性支床梁（軌道）上をばね・質点系（車両）が速度 $v$ で走行する解 析モデルを示す．レールを線密度 $\rho$, 曲げ剛性 EI のオイラー梁と仮定し, 片側のレールをモデル化する.レール を支持する弾性支床は, 図 2 に示すように, 軌道の支持構造によって, 一段, 二段, 三段弾性支床などがあるが, 機械インピーダンス $Z_{S}$ で一般化して表現している．車両は，片側レールに対応するため， 2 個の 1/2 輪軸（片側 の車輪と車軸, $\left.M_{a}, M_{b}\right)$ と $1 / 2$ 台車枠 $\left(M_{c}\right)$ と $1 / 4$ 車体 $\left(M_{d}\right)$ を質点として表現し，レールと車輪は剛に接触す る. $L$ は軸距（車輪の輪軸間の距離）である. なお車両の走行は, 車両を移動させずに走行速度に応じてレール 凹凸の位相を変化させることで模擬している.

\section{$2 \cdot 2$ 軌道の応答特性}

$x=0$ の 1 点において加振力 $f$ でレールを加振したときの波動方程式は，式(1)で表される.

$$
\rho \frac{\partial^{2} y}{\partial t^{2}}+E I \frac{\partial^{4} y}{\partial x^{4}}+i \omega Z_{s} y=f \delta(0)
$$

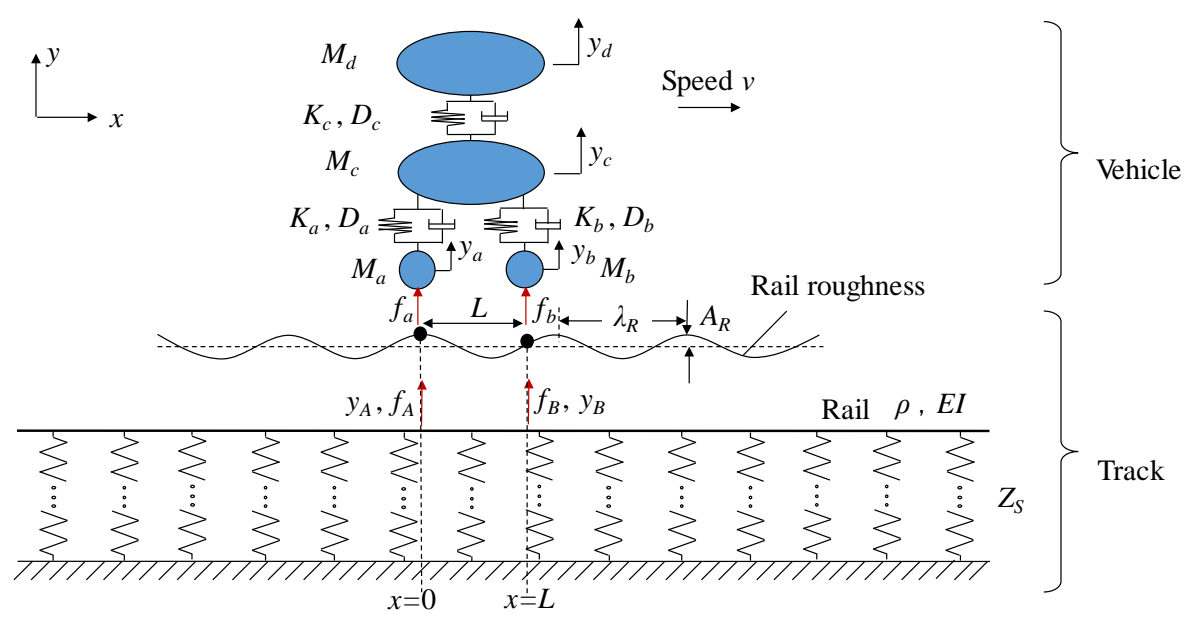

Fig.1 Analysis model with a continuously elastically supported beam (track) and a mass-spring system (vehicle).

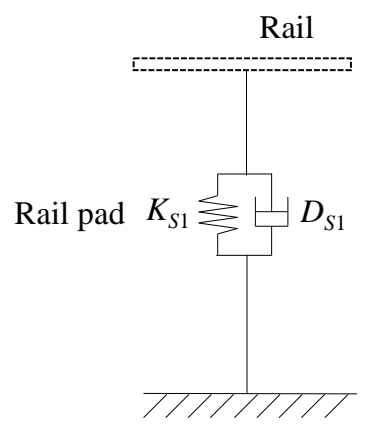

(a) Single spring

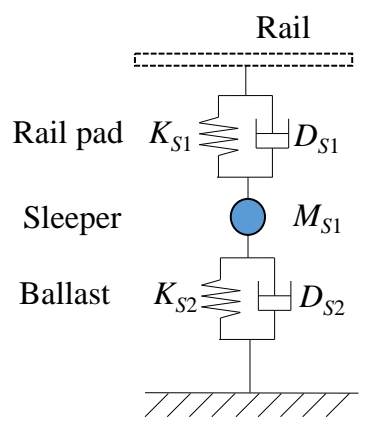

(b) Double spring

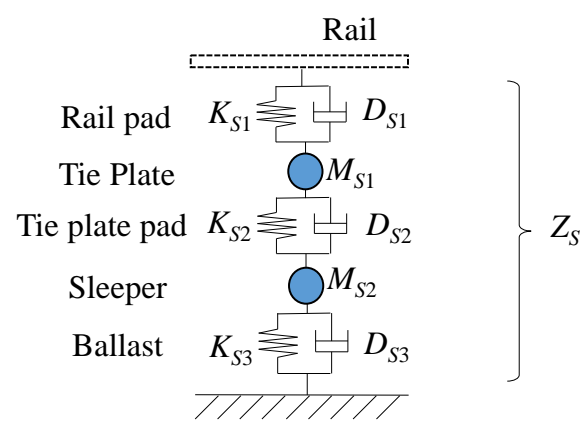

(c) Triple spring

Fig.2 Elastic support models as a railway track. 
ただし $, y, x, t$ はそれぞれレールの上下変位，長手方向の距離，時間であり， $\omega, i, \delta(x)$ はそれぞれ振動角周波 数, 虚数単位, ディラックのデルタ関数である.

ここでレールの上下変位を $y=A \exp (k x) \exp (i \omega t)$ とおいて, 式(1)の右辺を 0 とおいた特性方程式は式(2)で表され, その特性根（波数 $k$ ) は式(3)で表される.

$$
\begin{aligned}
& E I k^{4}+i \omega Z_{S}-\rho \omega^{2}=0 \\
& k= \pm \sqrt{ \pm \sqrt{\frac{\rho \omega^{2}-i \omega Z_{S}}{E I}}}
\end{aligned}
$$

ここで，4つの波数を $k_{1} \sim k_{4}$ とすれば，レールの上下変位 $y$ は一般に式(4)で表される.

$$
y=\left\{A_{1} \exp \left(k_{1} x\right)+A_{2} \exp \left(k_{2} x\right)+A_{3} \exp \left(k_{3} x\right)+A_{4} \exp \left(k_{4} x\right)\right\} \exp (i \omega t)
$$

ただし， $A_{1} \sim A_{4}$ は境界条件で定まる係数である. レールの上下変位 $y_{1}(x<0), y_{2}(x \geq 0)$ は，無限遠方の変位を 考慮して式(5)で表すことができる. ただし， $k_{1}, k_{3}$ を実数部が正のもの，また $k_{2}, k_{4}$ を実数部が負のものとし， 純虚数の場合は，波動伝播を考慮して， $k_{3}$ を正の純虚数， $k_{4}$ を負の純虚数と寸る.

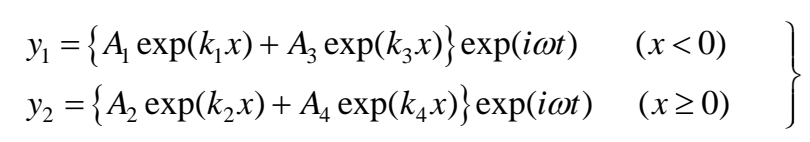

ここで, $f=F \exp (i \omega t)$ とし, $x=0$ でレールの変位, 傾斜, モーメントが連続し, さらにせん断力が釣り合うとし た境界条件から， $A_{1} \sim A_{4}$ は式(6)で求まる.

$$
\left.\begin{array}{l}
A_{1}=\frac{-1}{\left(k_{1}-k_{2}\right)\left(k_{1}-k_{3}\right)\left(k_{1}-k_{4}\right)} \cdot \frac{F}{E I} \\
A_{2}=\frac{1}{\left(k_{2}-k_{1}\right)\left(k_{2}-k_{3}\right)\left(k_{2}-k_{4}\right)} \cdot \frac{F}{E I} \\
A_{3}=\frac{-1}{\left(k_{3}-k_{1}\right)\left(k_{3}-k_{2}\right)\left(k_{3}-k_{4}\right)} \cdot \frac{F}{E I} \\
A_{4}=\frac{1}{\left(k_{4}-k_{1}\right)\left(k_{4}-k_{2}\right)\left(k_{4}-k_{3}\right)} \cdot \frac{F}{E I}
\end{array}\right\}
$$

これより, 加振点 $(x=0)$ における弾性支床梁の機械インピーダンス（以降, 加振点インピーダンスという） $Z_{R}$ は, 式(7)で表される. また, 波動伝播速度（位相速度）cは，式(8)で表される.

$$
\begin{aligned}
& Z_{R}=\frac{f}{d y_{2} /\left.d t\right|_{x=0}}=\frac{F}{i \omega\left(A_{2}+A_{4}\right)}=\frac{E I}{i \omega} \cdot \frac{\left(k_{1}-k_{2}\right)\left(k_{2}-k_{3}\right)\left(k_{3}-k_{4}\right)\left(k_{4}-k_{1}\right)}{k_{1}-k_{2}+k_{3}-k_{4}} \\
& C=\frac{\omega}{\left|\operatorname{Im}\left(k_{4}\right)\right|}
\end{aligned}
$$

\section{$2 \cdot 3$ レール凹凸振幅の成長機構}

上記で示した軌道の応答特性を 2 点の輪軸位置における加振によるものとして重ね合わせ, さらにレール凹凸 変位の変化（振動角周波数は $\omega=2 \pi v / \lambda_{R}$ ） と車両の応答特性を連成して解くことで，車輪とレール間の接触力（輪 重） $f_{A}, f_{B}$ を求めることができる. ここで, Archard の摩耗則（Archard，1953）に基づきレールが輪重に比例して 摩耗すると仮定すれば（金他，2009），凹凸のあるレール上を車両が走行したとき，1個の輪軸に換算して走行後 の凹凸振幅は走行前のそれに比べて 


$$
\kappa=\left|1+C_{W} H\right|
$$

倍となる.ここで， $C_{W}$ は単位輪重あたりのレール摩耗量，Hは上記の解析モデルから得られる凹凸振幅に対する

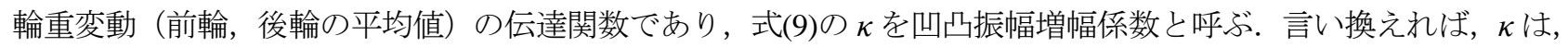
ある波長の凹凸上を車両が走行したときに， $\kappa>1$ ならばその凹凸振幅が増加（成長）し， $\kappa<1$ なら゙減少するこ とを示寸関数である。この お $C_{W}$ は，レール・車輪間の滑りや接線力，レールの硬さ，潤滑などの影響を受けると考えられるが，本論文で はこれらの影響を分離して $C_{W}$ を一定と仮定したうえで $\kappa$ の動力学的特性に着目する.

式(9)の伝達関数 $H$ は，軌道と車両の機械インピーダンス（加振点インピーダンス），軸距，加振角周波数 $\omega に$ よって決まる，簡単のため，1 輪軸のみでレールと車輪が接触する解析モデルを仮定し， $Z_{R}, Z_{V}$ をそれぞれ軌道 と車両の加振点インピーダンスとすれば，伝達関数 $H$ は式(10)で表される.

$$
H=-i \omega Z, \quad \text { ただし } Z=\frac{Z_{V} Z_{R}}{Z_{V}+Z_{R}}
$$

伝達関数 $H$ は軌道と車両の直列機械インピーダンスに比例するので，軌道の応答特性の変化は，この関係にお いて凹凸振幅増幅係数に影響を与える，実際には，図 1 の解析モデルで示すように，軌道と車両は複数箇所（一 般には 1 台車あたりレール片側で 2 点）で接触するため，これらの凹ら位相差やレール上を伝播する波動の影響 などが加わり複雑な様相を示す。したがって以降においては，軌道の応答特性に与える影響の代表として 1 点加 振時の軌道の加振点インピーダンス $Z_{R}$ を, またレール波状摩耗の成長機構に与える影響として凹凸振幅増幅係数 $\kappa の$ 計算例を基に考察する.

\section{$2 \cdot 4$ 計算例}

表 1 に，本論文で用いる軌道と車両の標準パラメータを示す．軌道の弾性支床の值はいずれも $1 \mathrm{~m}$ あたりの值 である．これらの值は，通常使用される軌道と車両の諸元を参考に概数として設定したものであり，整合性を考 えて前報告と同じ值としている，以降の章においては，特に断らない限りこれらの值を用いて計算する.

図 3 に, 表 1 の条件における軌道の加振点インピーダンス $Z_{R}$ の絶対值と波動伝播速度 $c$ の計算例を示す. 加振 点インピーダンスが極小となる周波数（二段弾性支床では約 $40 \mathrm{~Hz}$, 約 $275 \mathrm{~Hz}$ ) が弾性支床梁の共振周波数であり, 極大となる周波数（二段弾性支床では約 $165 \mathrm{~Hz}$ ） が反共振周波数である. 波動が伝播する領域は，共振周波数以 上または共振周波数〜反共振周波数間（二段，三段弾性支床の場合；二段弾性支床では約 40 約 $165 \mathrm{~Hz} ，$ 約 275 ～）であり，図3(b)の波動伝播速度は波動が伝播する領域のみを示している.

図 4 に，凹凸振幅増幅係数 $\kappa$ の計算例を示す．なお，空間周波数は波長の逆数を表し， $C_{W}$ は $10^{-15} \mathrm{~m} / \mathrm{N}$ とてい る. $\kappa$ が 1 以上でかつ極大となる要因は 4 つに分類することができ，図中の極大付近に示した丸付き数字は，(1) 軸距間でのレール波動の干渉によるもの，(2)軌道弾性支床の反共振現象によるもの，(3)軌道・車両全体系の反共

Table 1 An example of the model parameters.

(a) Track

\begin{tabular}{|l|c|c|c|}
\hline Parameter & single & double & triple \\
\hline$\rho(\mathrm{kg} / \mathrm{m})$ & 50 & 50 & 50 \\
\hline$\left.E I(\mathrm{Nm})^{2}\right)$ & $4 \times 10^{6}$ & $4 \times 10^{6}$ & $4 \times 10^{6}$ \\
\hline$K_{S 1}(\mathrm{~N} / \mathrm{m})$ & $10^{8}$ & $10^{8}$ & $10^{8}$ \\
\hline$D_{S 1}(\mathrm{Ns} / \mathrm{m})$ & $10^{3}$ & $10^{3}$ & $10^{3}$ \\
\hline$M_{S 1}(\mathrm{~kg})$ & & $10^{2}$ & $10^{1}$ \\
\hline$K_{S 2}(\mathrm{~N} / \mathrm{m})$ & & $10^{7}$ & $10^{8}$ \\
\hline$D_{S 2}(\mathrm{Ns} / \mathrm{m})$ & & $10^{3}$ & $10^{3}$ \\
\hline$M_{S 2}(\mathrm{~kg})$ & & & $10^{2}$ \\
\hline$K_{S 3}(\mathrm{~N} / \mathrm{m})$ & & & $10^{7}$ \\
\hline$D_{S 3}(\mathrm{Ns} / \mathrm{m})$ & & & $10^{3}$ \\
\hline
\end{tabular}

(b) Vehicle

\begin{tabular}{|l|c|}
\hline Parameter & \\
\hline$M_{a}, M_{b}(\mathrm{~kg})$ & $10^{3}$ \\
\hline$M_{c}(\mathrm{~kg})$ & $10^{3}$ \\
\hline$M_{d}(\mathrm{~kg})$ & $6 \times 10^{3}$ \\
\hline$K_{a}, K_{b}(\mathrm{~N} / \mathrm{m})$ & $10^{6}$ \\
\hline$D_{a}, D_{b}(\mathrm{Ns} / \mathrm{m})$ & 0 \\
\hline$K_{c}(\mathrm{~N} / \mathrm{m})$ & $10^{5}$ \\
\hline$D_{c}(\mathrm{Ns} / \mathrm{m})$ & 0 \\
\hline$L(\mathrm{~m})$ & 2.1 \\
\hline$v(\mathrm{~m} / \mathrm{s})$ & 15.12 \\
\hline
\end{tabular}




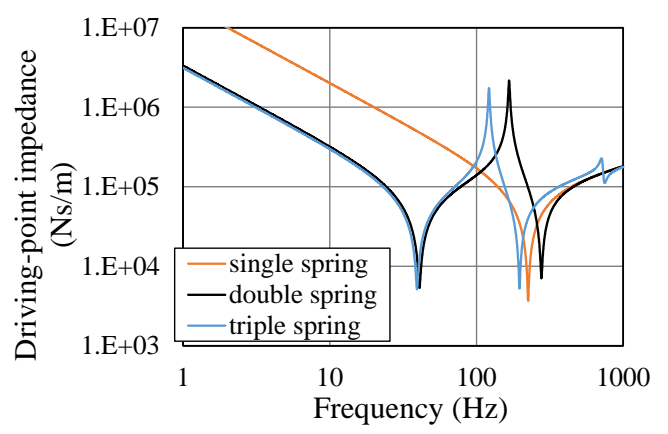

(a) Driving-point impedance (absolute value)

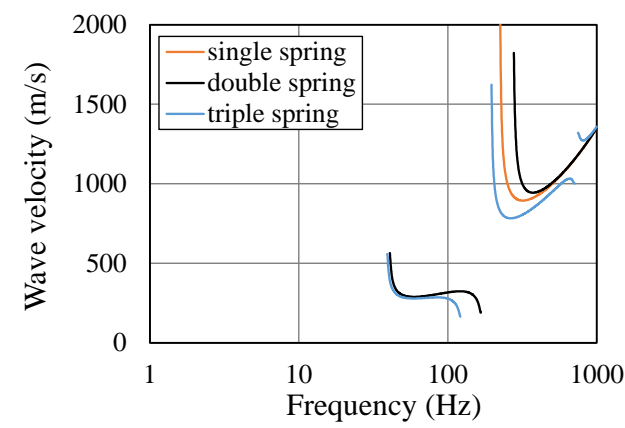

(b) Wave velocity

Fig. 3 Response characteristics of elastically supported beam model in condition of Table 1. In the case of double and triple spring, multiple resonance and anti-resonance phenomenon appear.

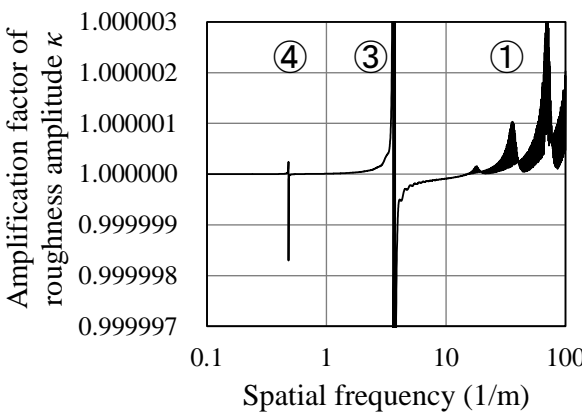

(a) Single spring

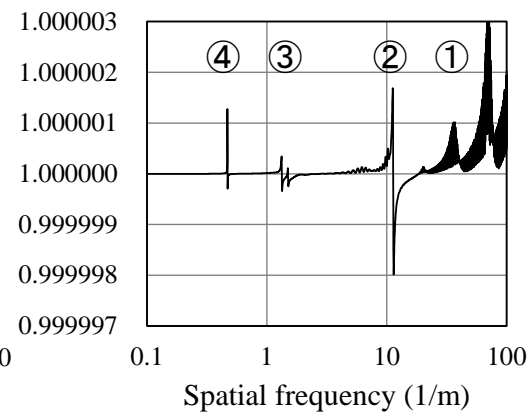

(b) Double spring

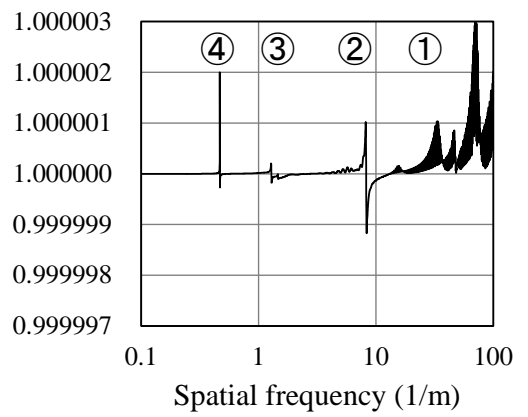

(c) Triple spring

Fig. 4 Amplification factor of roughness amplitude in the condition of Table 1. This amplitude indicates the growth degree of the rail corrugation. The growth factors of rail corrugation are (1)interference of rail wave motion between wheelbase of vehicle, (2)anti-resonance phenomenon at elastic support in track system, (3)anti-resonance phenomenon at total system of track and vehicle and (4)anti-resonance phenomenon at vehicle system.

振現象によるもの，(4)車両系の反共振現象によるものであることを示す.

図3(a)に示すように, 一段弾性支床では軌道の反共振現象が現れないこと，また三段弾性支床では共振周波数, 反共振周波数の数が二段弾性支床に比べて各々 1 個多い他は軌道の応答特性が比較的近いことから，以降の章に おける解析においては，二段弾性支床の計算例を示しながら検証する.

\section{3. レール軸力の影響}

前報告における解析モデルではレールの軸力を考慮していなかったが，本章では，レールの軸力が軌道の応答 特性とレール波状摩耗の成長機構に与える影響を検証する.

\section{$3 \cdot 1$ 軌道の応答特性}

軸力 $P$ が作用するレールを $x=0$ において加振力 $f$ で加振したときのレールの波動方程式は, 式(11)で表される. ただし，軸力 $P$ は引張側を正とする.

$$
\rho \frac{\partial^{2} y}{\partial t^{2}}+E I \frac{\partial^{4} y}{\partial x^{4}}-P \frac{\partial^{2} y}{\partial x^{2}}+i \omega Z_{s} y=f \delta(0)
$$

2 章と同様に, 式(11)右辺を 0 とおいた特性方程式は式(12)で表され, その特性根（波数 $k$ ）は式(13)で表される.

$$
E I k^{4}-P k^{2}+i \omega Z_{S}-\rho \omega^{2}=0
$$




$$
k= \pm \sqrt{\frac{P \pm \sqrt{P^{2}+4 E I\left(\rho \omega^{2}-i \omega Z_{S}\right)}}{2 E I}}
$$

これ以降は, 式(4)〜(8)と同様に, 軌道の加振点インピーダンスと波動伝播速度を求めることができる.

\section{$3 \cdot 2$ レール軸力変化量}

想定するレール軸力変化量については，以下のように考える．単位長さのレール両端を固定した場合，温度変 化による伸縮量 $\Delta L_{T}$ とレールの軸力変化による伸縮量 $\Delta L_{P}$ が釣り合うとすれば, 式(14)の関係が得られる.ただ し, $\Delta T, \Delta P, S_{R}, E_{R}, \alpha$ は, それぞれ温度変化量, 軸力変化量, レールの断面積, ヤング率, 線膨張係数である.

$$
\left(\Delta L_{T}=\right) \quad \alpha \Delta T=\frac{\Delta P}{S_{R} E_{R}} \quad\left(=\Delta L_{P}\right)
$$

ここで，レールの温度変化量を $\Delta T= \pm 35^{\circ} \mathrm{C}$ （最高 $60^{\circ} \mathrm{C}$ ，最低 $-10^{\circ} \mathrm{C｝ \text {）と仮定すれば，レールのヤング率 } E _ { R } = 2 . 1}$ $\times 10^{11} \mathrm{~N} / \mathrm{m}^{2}$, 線膨張係数 $\alpha=1.14 \times 10^{-5} /^{\circ} \mathrm{C}, 50 \mathrm{kgN}$ レールの断面積 $S_{R}=6.42 \times 10^{-3} \mathrm{~m}^{2}$ から , 軸力変化量 $\Delta P$ は $5.4 \times$ $10^{5} \mathrm{~N}$ 程度と見積もられる，以下の計算では，標準軸力を $0 \mathrm{~N}$ と，余裕をみて最大軸力を $\pm 10^{6} \mathrm{~N}$ とする.

\section{$3 \cdot 3$ 計算例}

図 5 に，表 1 に示寸二段弾性支床のパラメータを用いて，軌道の加振点インピーダンスの絶対值をレール軸力 $P$ で比較して示す. 全体として軸力変化量 $\Delta P= \pm 10^{6} \mathrm{~N}$ の範囲では軌道の応答特性に大きな差異は見られず, レー ル波状摩耗の成長機構に影響を与える反共振周波数（約 $165 \mathrm{~Hz}$ ）付近の加振点インピーダンスは $0.2 \%$ 以と差 異は小さい，一方，共振周波数（約 $40 \mathrm{~Hz}$ ）付近ならびに低周波においては，軸力が正側で機械インピーダンスが 増加する傾向が見られ，共振周波数（約 $40 \mathrm{~Hz}$ ）付近では土18\%程度，低周波の $10 \mathrm{~Hz}$ 付近では土4\%の差異となっ ている.これらは, 式(13)において, 反共振周波数付近では $Z_{s}$ が大きいため軸力 $P$ の影響が相対的に小さいこと, 一方，共振周波数付近では $\rho \omega^{2}-i \omega Z_{s}$ の項が 0 に近づくこと，また低周波では同項が小さくなることで，軸力 $P$ の 影響が相対的に大きくなることによるものと考えられる.

図 6 に，凹凸振幅増幅係数 $\kappa$ をレール軸力 $P$ で比較して示寸．全体としては大きな差異が見られないため，同 図(a)は(3)軌道・車両全体系の反共振現象による極大が現れる空間周波数約 1.5(1/m)付近を拡大したものであり, また同図(b)は(2)軌道弾性支床の反共振現象による極大が現れる空間周波数約 $11(1 / \mathrm{m})$ 付近を拡大したものである. いずれも大きな差異は見られないが, 空間周波数約 $11(1 / \mathrm{m})$ 付近で $\kappa に$ 変化が見られないのは, 軌道の加振点イン ピーダンスに差異が見られないためである.一方，1.5(1/m)付近の極大空間周波数にわずかに $\pm 0.03(1 / \mathrm{m})$ 程度の変 化が見られるのは，上述したように，低周波（この場合約 $23 \mathrm{~Hz}$ に相当）での軌道の加振点インピーダンスの絶 対值に土5\%程度の差異が見られることによると考えられる。

以上のことから，想定されるレール軸力の変化範囲では，レールの軸力が軌道の応答特性に与える影響ならび

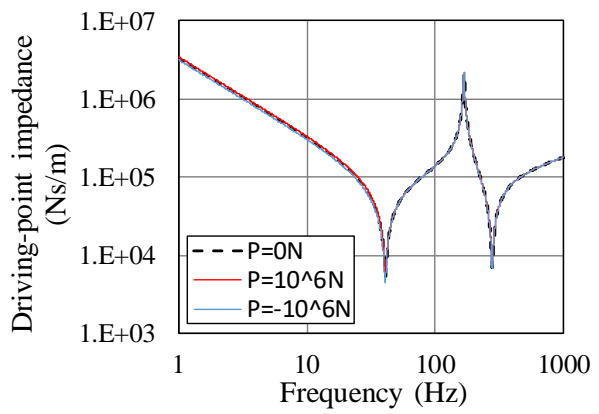

(a) Whole range

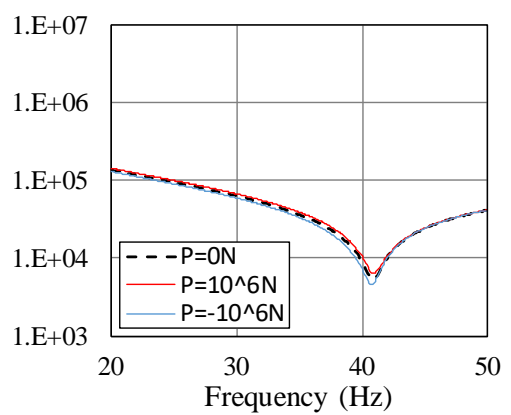

(b) Expansion of frequency $20 \sim 50 \mathrm{~Hz}$

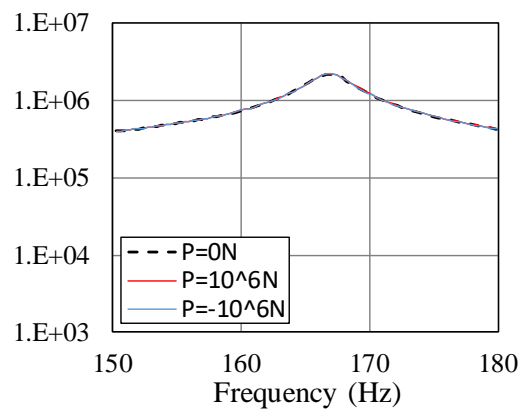

(c) Expansion of frequency $150 \sim 180 \mathrm{~Hz}$

Fig. 5 Effect of rail axial force on the driving-point impedance (absolute value) of track. Although a slight change appears near the resonance frequency and in low frequency side, a large difference is not seen as a whole. 


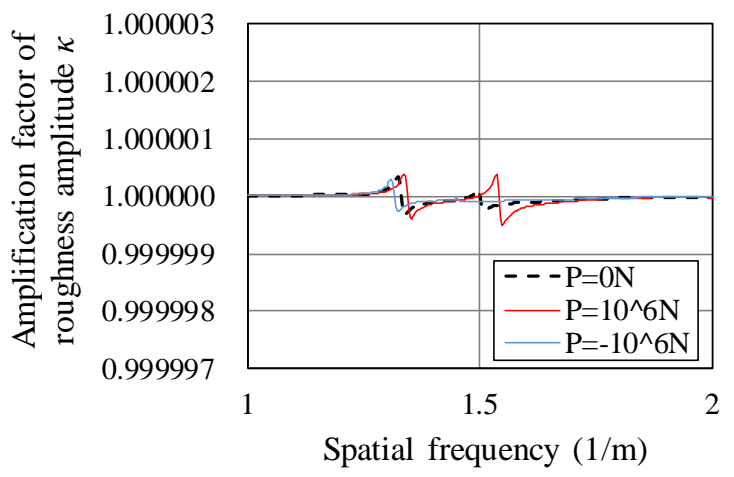

(a) Expansion of spatial frequency $1 \sim 2(1 / \mathrm{m})$

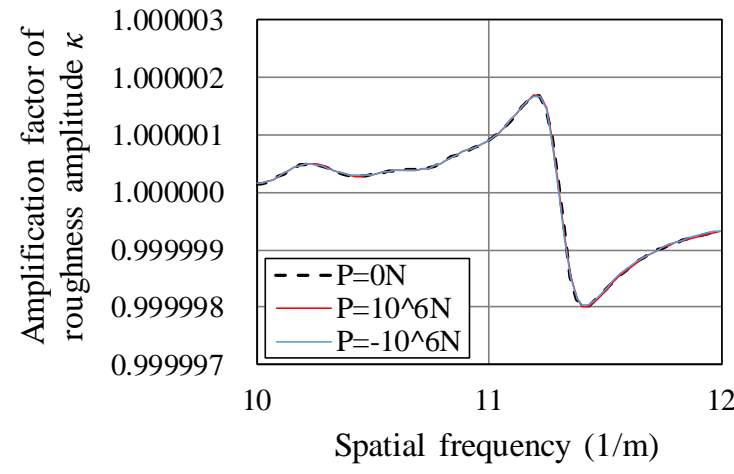

(b) Expansion of spatial frequency $10 \sim 12(1 / \mathrm{m})$

Fig. 6 Effect of rail axial force on amplification factor of roughness amplitude. Although there is a slight change only at around the spatial frequency $1.5(1 / \mathrm{m})$ (anti-resonance phenomenon at total system of track and vehicle), a large difference is not seen as a whole.

にレール波状摩耗の成長機構に与える影響は小さく，レール軸力を考慮しないで得られた前報告の結論は妥当と 考えられる．また，レール軸力は季節や天候により変化することや，絶対值を実測で把握することが容易ではな

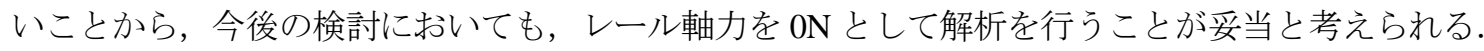

\section{4. 移動座標系による解析との差異}

前報告では，車両を移動させない解析モデル（静止座標系）においてレール凹凸の位相を変化させることで車 両走行を模擬していた，本章では，車両を移動させる解析モデル（移動座標系）で解析して静止座標系での解析 結果と比較することにより, 軌道の応答特性とレール波状摩耗の成長機構に与える影響を検証する.

\section{$4 \cdot 1$ 軌道の応答特性}

軌道を基準とする静止座標系において, 速度 $v$ で移動する加振力 $f$ で加振したときのレールの波動方程式は, 式(15)で表される．ただし，3章で得られた結果から，レール軸力は含めていない.

$$
\rho \frac{\partial^{2} y}{\partial t^{2}}+E I \frac{\partial^{4} y}{\partial x^{4}}+i \omega Z_{S} y=f \delta(x-v t)
$$

これを，加振位置を原点とする移動座標系 $(\xi=x-v t ， \tau=t)$ を用いて変換すると，

$$
\left.\begin{array}{l}
\frac{\partial y}{\partial x}=\frac{\partial y}{\partial \xi}, \quad \frac{\partial^{2} y}{\partial x^{2}}=\frac{\partial^{2} y}{\partial \xi^{2}}, \quad \frac{\partial^{4} y}{\partial x^{4}}=\frac{\partial^{4} y}{\partial \xi^{4}} \\
\frac{\partial y}{\partial t}=\frac{\partial y}{\partial \tau} \frac{\partial \tau}{\partial t}+\frac{\partial y}{\partial \xi} \frac{\partial \xi}{\partial t}=\frac{\partial y}{\partial \tau}-v \frac{\partial y}{\partial \xi}, \quad \frac{\partial^{2} y}{\partial t^{2}}=\frac{\partial^{2} y}{\partial \tau^{2}}-2 v \frac{\partial^{2} y}{\partial \tau \partial \xi}+v^{2} \frac{\partial^{2} y}{\partial \xi^{2}}
\end{array}\right\}
$$

であるので，式(15)を移動座標系に変換すると式(17)で表される．ただし， $\tau$ を $t$ に戻して表記している.

$$
\rho \frac{\partial^{2} y}{\partial t^{2}}-2 \rho v \frac{\partial^{2} y}{\partial t \partial \xi}+\rho v^{2} \frac{\partial^{2} y}{\partial \xi^{2}}+E I \frac{\partial^{4} y}{\partial \xi^{4}}+i \omega Z_{S} y=f \delta(\xi)
$$

レールの上下変位を $y=A \exp (k \xi) \exp (i \omega t)$ とおいて, 式(17)右辺を 0 とおいた特性方程式は式(18)で表される.

$$
E I k^{4}+\rho v^{2} k^{2}-i 2 \rho v \omega k+i \omega Z_{S}-\rho \omega^{2}=0
$$


これから得られる特性根（波数 $k_{1} \sim k_{4}$ ）を 2 章と同様に定め，また $f=F \exp (i \omega t)$ とおくと，加振点 $\xi=0$ における境 界条件から，レールの上下変位 $y_{1}(\xi<0), y_{2}(\xi \geq 0)$ は，式(5)と同様に式(19)で表される.

$$
\left.\begin{array}{ll}
y_{1}=\left\{A_{1} \exp \left(k_{1} \xi\right)+A_{3} \exp \left(k_{3} \xi\right)\right\} \exp (i \omega t) & (\xi<0) \\
y_{2}=\left\{A_{2} \exp \left(k_{2} \xi\right)+A_{4} \exp \left(k_{4} \xi\right)\right\} \exp (i \omega t) & (\xi \geq 0)
\end{array}\right\}
$$

これ以降は, 式(6) (7)と同様に, 加振点 $(\xi=0)$ における軌道の加振点インピーダンス $Z_{R} を$ 求めることができる. なお，波動伝播速度は静止座標系で表すのが通常なので，ここでは示さない.

\section{$4 \cdot 2$ 計算例}

図 7 に, 表 1 に示寸二段弾性支床のパラメータを用いて, 走行速度を $0 \mathrm{~m} / \mathrm{s}, 30 \mathrm{~m} / \mathrm{s}(108 \mathrm{~km} / \mathrm{h}), 100 \mathrm{~m} / \mathrm{s}(360 \mathrm{~km} / \mathrm{h})$ としたときの軌道の加振点インピーダンス $Z_{R}$ の絶対值を比較して示寸. なお走行速度 $0 \mathrm{~m} / \mathrm{s}$ の值は, 静止座標系 で計算した值と同じである.

同図(a)は全体の周波数範囲で示しているが, 全体的に大きな差異は見られない. 同図(b)は軌道の共振周波数 (約 $40 \mathrm{~Hz})$ 付近を拡大して示すが, 静止状態 $(v=0 \mathrm{~m} / \mathrm{s})$ に対して速度が高いほど共振周波数での加振点インピーダン スが増加し，また共振周波数が若干低下寸る傾向が見られる. 例えば速度 $30 \mathrm{~m} / \mathrm{s}$ では, 走行速度 $0 \mathrm{~m} / \mathrm{s}$ に対して加 振点インピーダンスは $20 \%$ 程度増加し, 共振周波数は $0.7 \%$ 低下寸る. 一方, 同図(c)は軌道の反共振周波数（約 $165 \mathrm{~Hz}$ ）付近を拡大して示寸が，速度による差異はほとんど見られない．これらは，式(2)と式(18)を比較すると， 共振周波数付近では $\rho \omega^{2}-i \omega Z_{S}$ の項が 0 に近づくことで, 移動座標系で加わった $\rho v^{2} k^{2}-i 2 \rho v \omega k$ 項の影響が相対的に 大きくなること，一方，反共振周波数付近では $Z_{S}$ が大きいため，同項の影響が相対的に小さいことによるものと

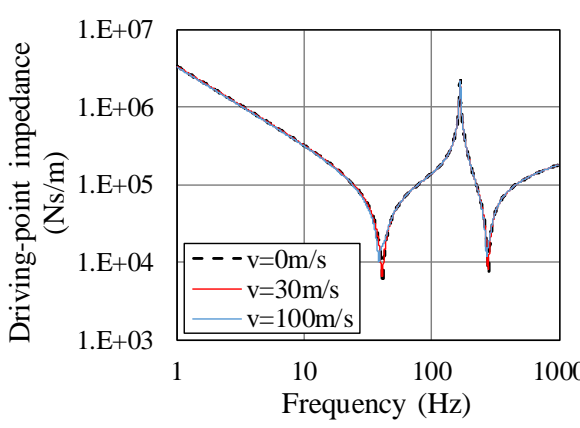

(a) Whole range

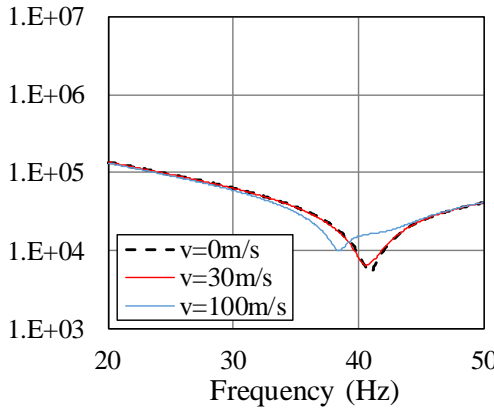

(b) Expansion of frequency $20 \sim 50 \mathrm{~Hz}$

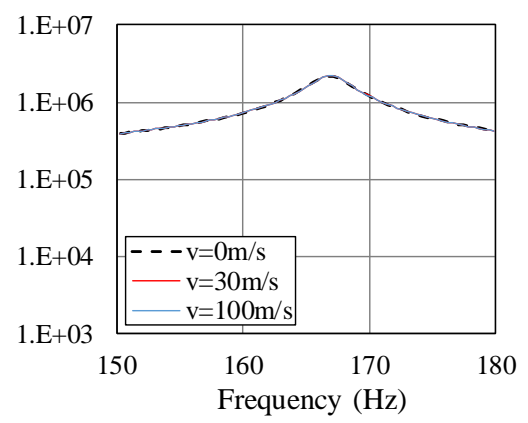

(c) Expansion of frequency $150 \sim 180 \mathrm{~Hz}$

Fig. 7 Comparison of driving-point impedance (absolute value) between analysis by static coordinate ( $0 \mathrm{~m} / \mathrm{s}$ ) and analysis by moving coordinate $(30 \mathrm{~m} / \mathrm{s}, 100 \mathrm{~m} / \mathrm{s})$. Although a slight change appears only near the resonance frequency, a large difference is not seen as a whole.

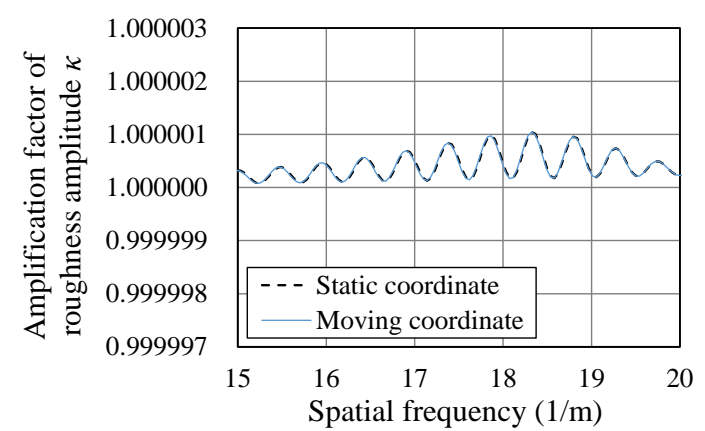

(a) $v=30 \mathrm{~m} / \mathrm{s}(108 \mathrm{~km} / \mathrm{h})$

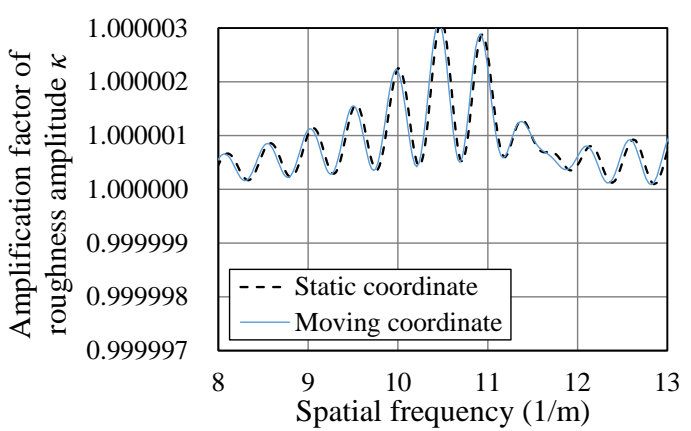

(b) $v=100 \mathrm{~m} / \mathrm{s}(360 \mathrm{~km} / \mathrm{h})$

Fig. 8 Comparison of amplification factor of roughness amplitude between analysis by static coordinate and analysis by moving coordinate $(30 \mathrm{~m} / \mathrm{s}, 100 \mathrm{~m} / \mathrm{s})$. Although there is a slight change only in high spatial frequency (interference of rail wave motion between wheelbase of vehicle), a large difference is not seen as a whole. 


\section{考えられる.}

図 8 に, 速度 $30 \mathrm{~m} / \mathrm{s}$ と $100 \mathrm{~m} / \mathrm{s}$ における静止座標系と移動座標系の解析モデルによる凹凸振幅増幅係数 $\kappa$ の計算 結果を比較して示す．全体的に大きな差異は見られないが，波動が伝播する比較的高い空間周波数において，(1) 軸距間でのレール波動の干渉による極大付近において若干の差異が見られる．極大值の大きさはほぼ同等だが， 極大となる空間周波数が若干低下しており，30 m/s で 0.01(1/m)程度， $100 \mathrm{~m} / \mathrm{s}$ で $0.03(1 / \mathrm{m})$ 程度低下している. 図 8 に示した空間周波数付近において，走行速度のレール波動伝播速度に対する比は，走行速度 $30 \mathrm{~m} / \mathrm{s}$ で 0.03 程度， $100 \mathrm{~m} / \mathrm{s}$ で 0.08 程度と小さく，ドップラー効果の影響が比較的小さいことによると考えられる.

以上のことから，通常の軌道構造と速度範囲においては，移動座標系で解析した結果は静止座標系のそれと大 きな差異はなく，静止座標系での解析で得られた前報告の結論は妥当と考えられる.

\section{5.＼cjkstart離散支持を連続支床でモデル化する場合の差異}

前報告では，軌道弾性支床の反共振周波数付近において，離散支持モデル（実際の軌道構造）と連続支床モデ ル（弾性支床梁モデル）で振動形態が異なることが課題として残っていた．本章では，離散支持モデルにおける 単位セルの固有值と, 弾性支床梁モデルにおいてそれに相当する伝達係数を比較することで, この差異を検証す る.

\section{$5 \cdot 1$ 伝達係数の比較}

図 9(a)に，軌道の離散支持モデル（単位セル）を示す．前報告で示したように，単位セル両端のレール変位間 の関係を伝達マトリックスとして求め，その固有值を解析することで，単位セル間の振動伝達特性を示すことが できる. 計算条件として, レールの支持間隔 $L_{S}$ を $0.6 \mathrm{~m}$ とし, 単位セルのばね定数 $K_{D 1}, K_{D 2}$, 減衰係数 $D_{D 1}, D_{D 2}$, 質量 $M_{D 1}$ は，表 1 の $1 \mathrm{~m}$ あたりの值に支持間隔 $L_{S}$ を乗じて式(20)で設定する.

$$
\left.\begin{array}{l}
K_{D 1}=L_{S} K_{S 1}, \quad K_{D 2}=L_{S} K_{S 2} \\
D_{D 1}=L_{S} D_{S 1}, \quad D_{D 2}=L_{S} D_{S 2} \\
M_{D 1}=L_{S} M_{S 1}
\end{array}\right\}
$$

一方，図 9(b)に示すように，離散支持モデルにおける単位セルの固有值に相当する值として，前報告と同様に, 弾性支床梁モデルにおける伝達距離 $L_{S}$ 間の伝達係数 $\gamma_{n}$ を式(21)により求める. ただし， $k_{n}$ は波動方程式から得ら れる波数である.

$$
\gamma_{n}=\frac{A_{n} \exp \left(k_{n} L_{S}\right)}{A_{n}}=\exp \left(k_{n} L_{S}\right) \quad(n=1 \sim 4)
$$

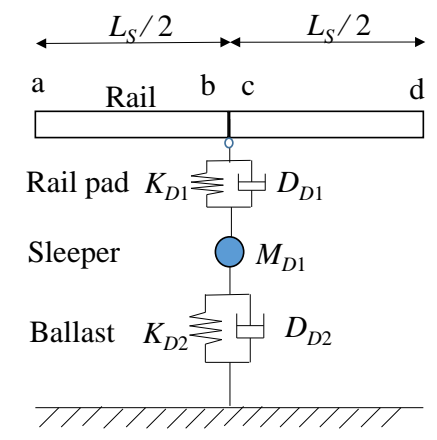

(a) Unit cell of discrete support model

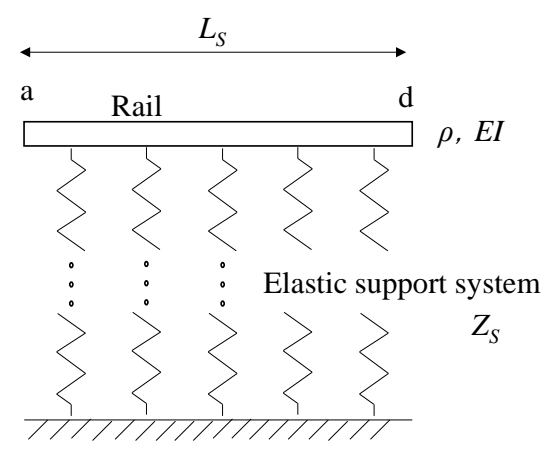

(b) Continuous support model (elastically supported beam model)

Fig. 9 Discrete support model and continuous support model as a track system. 

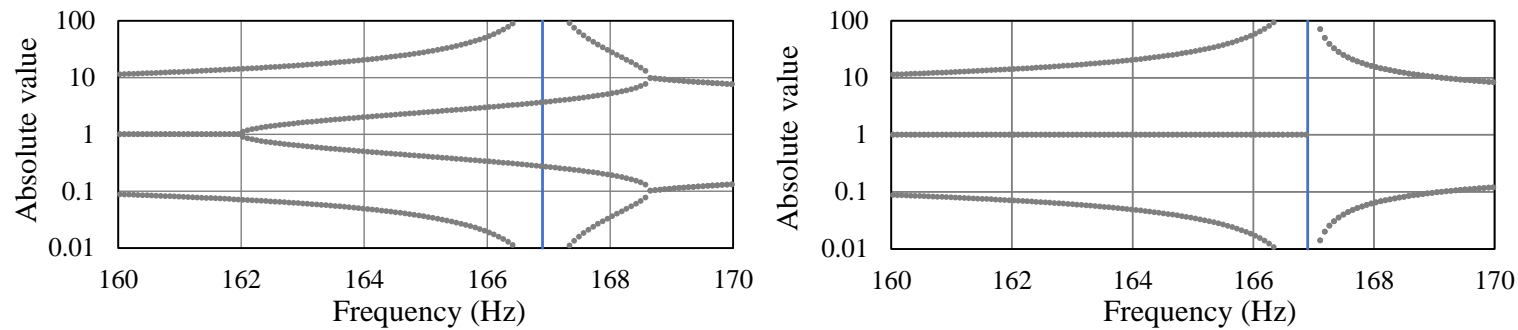

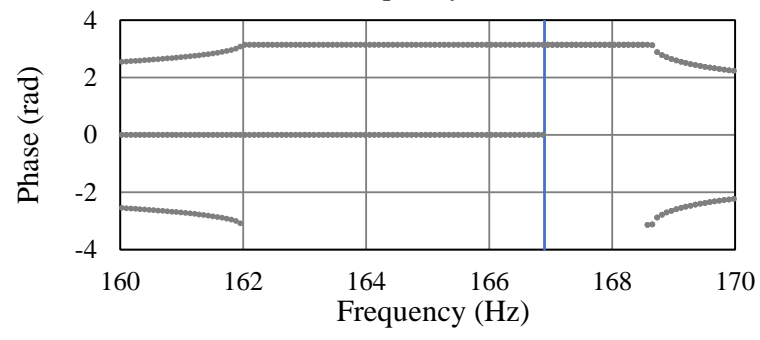

(a) Discrete support model

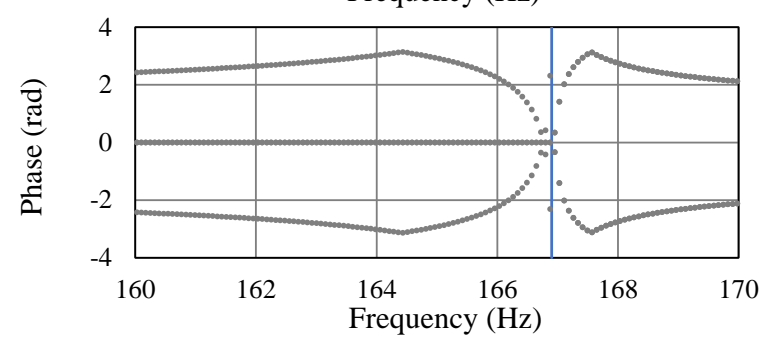

(b) Continuous support model

Fig. 10 Comparison of transmission coefficients between discrete support model and continuous support model $\left(D_{S 1}, D_{S 2}=\right.$ $0 \mathrm{Ns} / \mathrm{m}$ ). Around the anti-resonance frequency of elastic support in track system $166.9 \mathrm{~Hz}$, both transmission characteristics differ greatly.
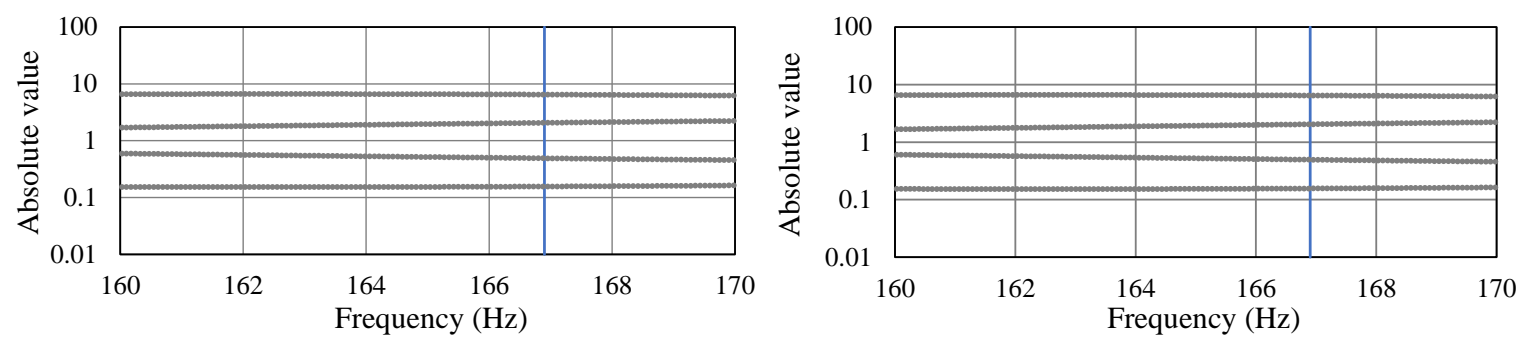

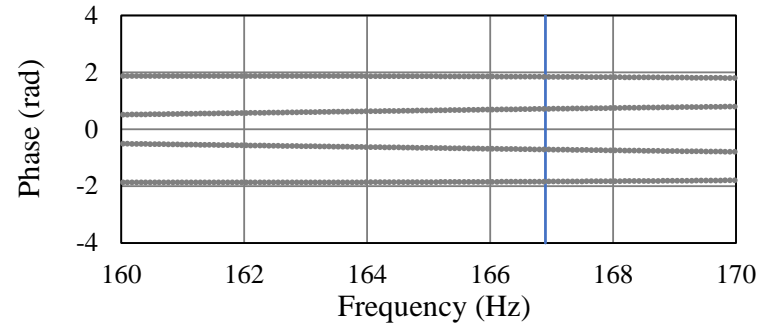

(a) Discrete support model

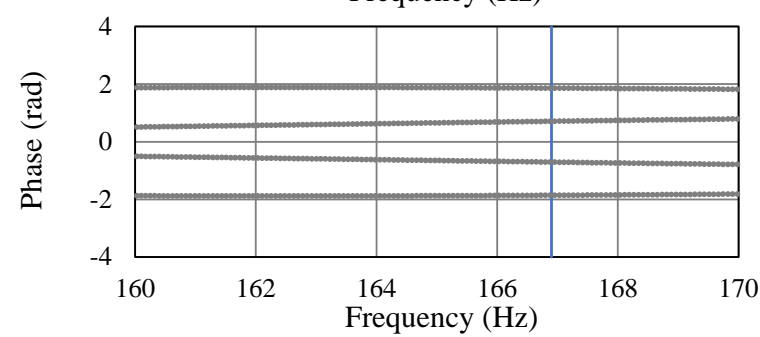

(b) Continuous support model

Fig. 11 Comparison of transmission coefficients between discrete support model and continuous support model $\left(D_{S 1}, D_{S 2}=\right.$ $\left.10^{4} \mathrm{Ns} / \mathrm{m}\right)$. Both transmission characteristics agree well even near the anti-resonance frequency of elastic support in track system.

図 10 に，軌道弾性支床の反共振周波数（約 $165 \mathrm{~Hz}$ ）付近における離散支持モデルの固有值と連続支床モデルの 伝達係数を比較して示す. 軌道弾性支床の減衰係数 $D_{S 1}, D_{S 2}=0 \mathrm{Ns} / \mathrm{m}$ （単位セルの減衰係数 $D_{D 1}, D_{D 2}=0 \mathrm{Ns} / \mathrm{m}$ ） と して計算したものであるが，この図は前報告で示したものと同じである. 離散支持モデルでは，反共振周波数 (こ の場合，正確には $166.9 \mathrm{~Hz}$; 図中の青線）より高周波側において全ての固有值が反位相となる周波数が存在し， これは支持点を節とする振動形態となるが，連続支床モデルではそのような振動形態は見られない。

一方，図 11 に，軌道弾性支床の減衰係数 $D_{S 1}, D_{S 2}=10^{4} \mathrm{Ns} / \mathrm{m} （$ 単位セルの減衰係数 $\left.D_{D 1}, D_{D 2}=0.6 \times 10^{4} \mathrm{Ns} / \mathrm{m}\right)$ と したときの離散支持モデルの固有值と連続支床モデルの伝達係数を比較して示す．軌道弾性支床の減衰を考慮す ることで反共振周波数付近の特性変化が緩やかになり，離散支持モデルにおいても支持点を節とする振動形態が 見られなくなる．また，連続支床の伝達係数との差異も小さくなり，反共振周波数（166.9Hz）における4つの伝 
達係数の誤差の平均は $1.1 \%$ 小さい.

上記で仮定した軌道弾性支床の減衰係数は，例えば軌道パッドの一般的な材料であるゴムを想定した場合，損 失係数を 0.2 程度, ばね定数を $10^{8} \mathrm{~N} / \mathrm{m}$ として $166.9 \mathrm{~Hz}$ における減衰係数に換算すると $3.2 \times 10^{4} \mathrm{Ns} / \mathrm{m}$ （1m あたり） であるので, 妥当と考えられる. 今後, バラストや路盤なども含めて減衰係数を実軌道で確認寸る必要があるが, 通常の軌道構造であれば，離散支持モデルと連続支床モデルとの振動形態の差異は小さいと考えられる.

\section{$5 \cdot 2$ 運動シミュレーションによる挙動検証}

軌道弹性支床の反共振周波数付近での振動形態を確認寸るため, レール波状摩耗の進展解析のための運動シミ ユレーション手法（網干，田中，2019b）を用いてその挙動を確認する. シミュレーションモデルではレールは離 散支持されており，レールの支持間隔や軌道条件は前節と同じと寸る. 加振力は振幅 $1 \mathrm{~N}$ の正弦波とし，加振位 置はレールの支持点間の中央とする.

図 12 に, レールを $166.9 \mathrm{~Hz}$ で加振したときのある時刻におけるレールの変位形状を示す. 同図(a)は軌道の減 衰係数 $D_{D 1}, D_{D 2}=0 \mathrm{Ns} / \mathrm{m}$ とした場合で，支持点を節とした振動形態となっていることがわかる．一方，同図(b)は 軌道の減衰係数 $D_{D 1}, D_{D 2}=0.6 \times 10^{4} \mathrm{Ns} / \mathrm{m}$ とした場合で，支持点を節とした振動形態にはなっていないことがわか る.

図 13 に, 軌道の減衰係数 $\left.D_{S 1}, D_{S 2}=10^{4} \mathrm{Ns} / \mathrm{m} （ D_{D 1}, D_{D 2}=0.6 \times 10^{4} \mathrm{Ns} / \mathrm{m}\right)$ とした場合の, 運動シミュレーションに よって得られる反共振周波数 $166.9 \mathrm{~Hz}$ における加振点インピーダンス（2 秒間加振の後半 1 秒間における加振力 の応答速度に対する比）と, 弾性支床梁モデルで計算される加振点インピーダンスを比較して示寸. 軌道弾性支

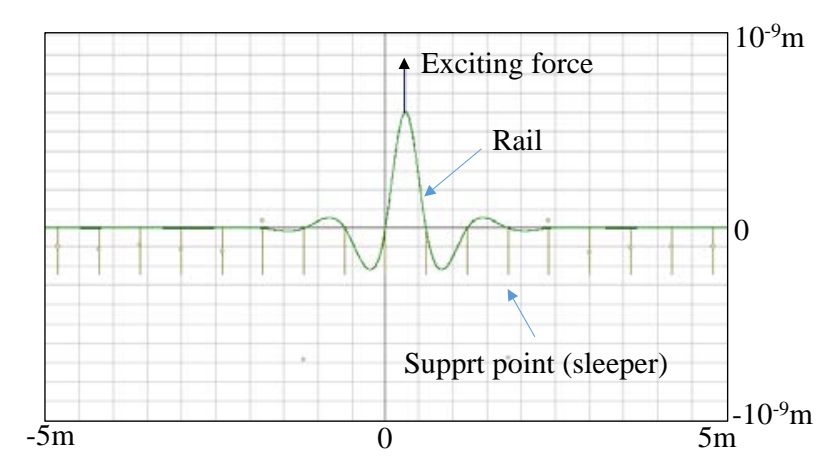

(a) $D_{D 1}, D_{D 2}=0 \mathrm{Ns} / \mathrm{m}$

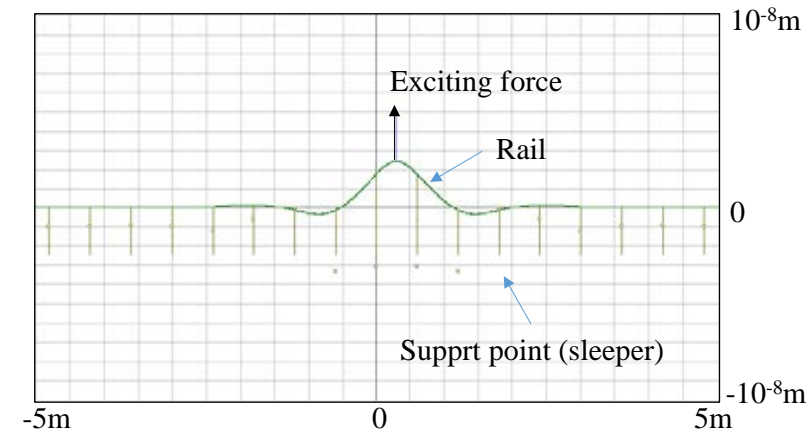

(b) $D_{D 1}, D_{D 2}=0.6 \times 10^{4} \mathrm{Ns} / \mathrm{m}$

Fig. 12 Comparison of vibration waveforms in condition of damping coefficient of elastic support. There is a vibration mode in which the support point becomes a node in the condition of $0 \mathrm{Ns} / \mathrm{m}$. On the other hand, no such vibration mode is seen in the condition of $10^{4} \mathrm{Ns} / \mathrm{m}$.

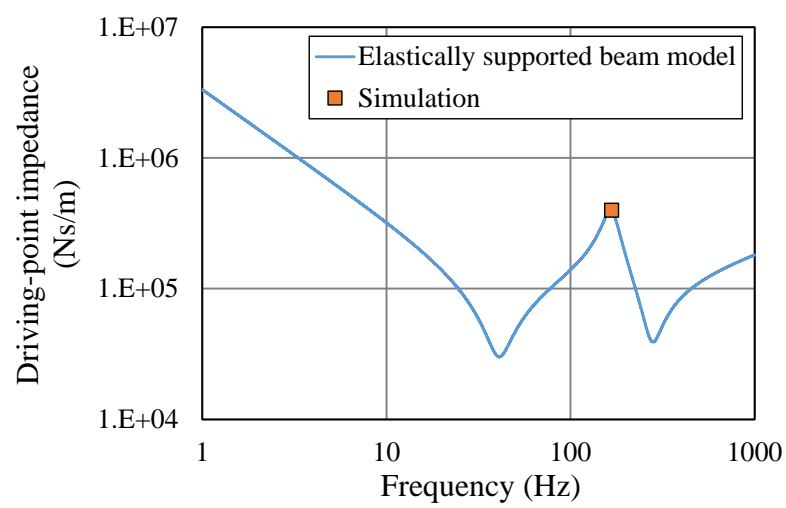

Fig. 13 Comparison of driving-point impedance between discrete support model (simulation) and continuous support model (analysis by elastically supported beam model). 
床の反共振周波数においては，離散支持モデル（シミュレーション結果）と連続支床モデル（弾性支床梁モデル による解析）による值は，1\%以下の誤差で一致する．なお，加振位置をレールの支持点とした場合も別途計算し ており，同様に1\%以下の誤差で一致することを確認している.

以上のことから，通常の軌道構造の場合であれば，軌道弾性支床の反共振周波数付近を含めて，離散支持モデ ルと連続支床モデルとの特性差は小さく, 弾性支床梁モデルから得られた前報告の結論は妥当であると考えられ る.

\section{6. 結 言}

本論文では，前報告（網干，田中，2019a）で残されていた軌道の弾性支床梁モデルにおける課題について，こ れらの要因が軌道の応答特性ならびにレール波状摩耗の成長機構に与える影響を検証した. 主な結果をまとめる と，以下のとおりである.

(1)想定されるレール軸力の変化範囲では, レール軸力が軌道の応答特性に与える影響ならびにレール波状摩耗の 成長機構に与える影響は小さく, レール軸力を考慮しないで得られた前報告の結論は妥当と考えられる.

(2)通常の軌道構造と速度範囲においては, 移動座標系で解析した結果は静止座標系のそれと大きな差異はなく, 静止座標系での解析で得られた前報告の結論は妥当と考えられる.

(3)通常の軌道構造の場合であれば, 軌道弾性支床の反共振周波数付近を含めて, 離散支持モデルと連続支床モデ ルとの特性差は小さく, 弾性支床梁モデルでの解析から得られた前報告の結論は妥当であると考えられる.

(4)以上のことから, 軌道の弾性支床梁モデルを用いて説明されるレール波状摩耗の成長機構および波長決定メカ ニズムに関する前報告の結論は妥当と考えられる.

\section{文献}

網干光雄，田中博文，レール波状摩耗の成長機構に関する理論解析，日本機械学会論文集，Vol.85, No.875 (2019a), DOI:10.1299/transjsme.18-00426.

網干光雄，田中博文，レール波状摩耗の進展仮定に関するシミュレーション解析，日本機械学会論文集，Vol.85， No.878 (2019b), DOI:10.1299/transjsme.19-00051.

Archard, J. F., Contact and rubbing of flat surface, Journal of Applied Physics, Vol.24, No.8 (1953), pp.981-988.

Grassie, S. L. and Kalousek, J., Rail corrugation: characteristics, causes and treatments, Proc.IMechE, Part F, Vol. 207 (1993), pp.57-68.

Igeland, A., Railhead corrugation growth explained by dynamic interaction between track and bogie wheelsets, Proc.IMechE, Part F, Vol. 210 (1996), pp.11-20.

石田誠，車両とレールコルゲーション（その 1～5), R\&m, Vol.13, No.8〜12 (2005).

金鷹，名村明，石田誠，レール頭部の摩耗形状予測手法，鉄道総研報告，Vol.23，No.2 (2009), pp.5-10.

Manabe, K., A hypothesis on a wavelength fixing mechanism of rail corrugation, Proc.IMechE, Part F, Vol. 214 (2000), pp.21-26.

松本陽, 佐藤安弘, 藤井雅子, 谷本益久, 陸康思, 曲線部に発生するレール波状摩耗の発生メカニズムに関する 研究（第 1 報），日本機械学会論文集 C 編，Vol. 62, No. 597 (1996), pp.49-57.

須田義大, 井口雅一, 今泉博英, 谷口雅昭, コルゲーションの成長・減衰機構の研究 (第 1 報), 日本機械学会論 文集 C 編，Vol. 54, No. 499 (1988), pp.537-543.

田中博文, 松田博之, 輪田朝亮, 急曲線外軌波状摩耗発生区間のレール／車輪間の接触力学に関する考察, 鉄道 力学論文集, No.13 (2009), pp.43-50.

\section{References}

Aboshi, M. and Tanaka, H., Theoretical analyses of growth mechanism of rail corrugation, Transactions of the JSME (in Japanese), Vol.85, No.875 (2019a), DOI:10.1299/transjsme.18-00426.

Aboshi, M. and Tanaka, H., "Simulation analyses of progress process of rail corrugation, Transactions of the JSME (in 
Japanese), Vol.85, No.878 (2019b), DOI:10.1299/transjsme.19-00051.

Archard, J. F., Contact and rubbing of flat surface, Journal of Applied Physics, Vol.24, No.8 (1953), pp.981-988.

Grassie, S. L. and Kalousek, J., Rail corrugation: characteristics, causes and treatments, Proc.IMechE, Part F, Vol. 207 (1993), pp.57-68.

Igeland, A., Railhead corrugation growth explained by dynamic interaction between track and bogie wheelsets, Proc.IMechE, Part F, Vol. 210 (1996), pp.11-20.

Ishida, M., Vehicle and rail corrugation (1 5), R\&m, Vol.13, No.8〜12 (2005) (in Japanese).

Jin, Y., Namura, A. and Ishida, M., A predictive method of wear profile of rail head, RTRI Report, Vol.23, No.2 (2009), pp.5-10 (in Japanese).

Manabe, K., A hypothesis on a wavelength fixing mechanism of rail corrugation, Proc.IMechE, Part F, Vol. 214 (2000), pp.21-26.

Matsumoto, A., Sato, Y., Fujii, M., Tanimoto, M. and Oka, Y., Formation Mechanism if rail corrugation on curved track (1st report), Transactions of the Japan Society of Mechanical Engineers, Series C, Vol. 62, No. 597 (1996), pp.49-57 (in Japanese).

Suda, Y., Iguchi, M., Imaizumi, H. and Taniguchi, M., The mechanism of corrugation phenomenon on rolling surfaces (1st report), Transactions of the Japan Society of Mechanical Engineers, Series C, Vol. 54, No. 499 (1988), pp.537-543 (in Japanese).

Tanaka, H., Matsuda, H. and Wada, T., Study on corrugation generated on high rail in sharp curves based on the contact mechanics between rail/wheel, Journal of railway mechanics, No.13 (2009), pp.43-50 (in Japanese). 